\title{
Cryptococcus neoformans carried by Odontomachus bauri ants
}

\author{
Mariana Santos de Jesus ${ }^{1}$, William Costa Rodrigues², Glaucia Barbosa ${ }^{3}$, \\ Luciana Trilles ${ }^{3}$, Bodo Wanke ${ }^{3}$, Márcia dos Santos Lazéra ${ }^{3} /{ }^{+}$, Manuela da Silva ${ }^{4}$ \\ 1Programa de Pós-Graduação em Recursos Genéticos Vegetais, Universidade Estadual de Feira de Santana, Feira de Santana, BA, Brasil \\ ${ }^{2}$ Universidade Severino Sombra, Centro de Ciências Exatas, Tecnológicas e da Natureza, Vassouras, RJ, Brasil \\ ${ }^{3}$ Laboratório de Micologia, Instituto de Pesquisa Clínica Evandro Chagas ${ }^{4}$ Programa de Pós-Graduação em Vigilância Sanitária, \\ Instituto Nacional de Controle de Qualidade em Saúde-Fiocruz, Av. Brasil 4365, 21045-900 Rio de Janeiro, RJ, Brasil
}

Cryptococcus neoformans is the most common causative agent of cryptococcosis worldwide. Although this fungus has been isolated from a variety of organic substrates, several studies suggest that hollow trees constitute an important natural niche for $\mathrm{C}$. neoformans. A previously surveyed hollow of a living pink shower tree (Cassia grandis) positive for $\mathrm{C}$. neoformans in the city of Rio de Janeiro, Brazil, was chosen for further investigation. Odontomachus bauri ants (trap-jaw ants) found inside the hollow were collected for evaluation as possible carriers of Cryptococcus spp. Two out of 10 ants were found to carry phenoloxidase-positive colonies identified as $\mathrm{C}$. neoformans molecular types VNI and VNII. The ants may have acted as a mechanical vector of $\mathrm{C}$. neoformans and possibly contributed to the dispersal of the fungi from one substrate to another. To the best of our knowledge, this is the first report on the association of $\mathrm{C}$. neoformans with ants of the genus Odontomachus.

Key words: Cryptococcus neoformans - Odontomachus bauri - insect association - hollow tree habitat

Hollows from tree trunks have been investigated as potential sources of Cryptococcus gattii and Cryptococcus neoformans, the two causative agents of cryptococcosis, a life-threatening systemic mycosis affecting humans and a wide range of animals (Kwon-Chung \& Varma 2006, Lin \& Heitman 2006). Interest in this ecological niche began with the isolation of $C$. gattii from bark and wood debris collected from the hollow of a $E u$ calyptus tree in Australia (Pfeiffer \& Ellis 1992) and the isolation of $C$. neoformans from wood and plant debris collected from the hollow of a Syzygium jambolanum tree (java plum tree) from an urban environment in the city of Rio de Janeiro, Brazil (Lazéra et al. 1993). Following this study, the hollows of several species of living trees in the same geographical region were investigated and numerous strains of $C$. neoformans were found (Lazéra et al. 1996). In addition to these two surveys, there have been other investigations on the hollow trunks of living trees in different regions of Brazil and in other countries, such as Colombia, India and Argentina, from which several representative colonies of $C$. gattii and C. neoformans were isolated, demonstrating that tree hollows are a suitable ecological niche for both species (Lazéra et al. 1998, 2000, Fortes et al. 2001, Granados \& Castañeda 2006, Baltazar \& Ribeiro 2008, Costa et al. 2009, Kumar et al. 2009, Refojo et al. 2009, Mitchell et al. 2011).

These pathogenic capsulated yeasts, which have as their teleomorphic state the genus Filobasidiella, belong

Financial support: FAPERJ (E-26/110.486/2007)

+ Corresponding author: marcia.lazera@ipec.fiocruz.br

Received 26 July 2011

Accepted 7 December 2012 to the class Tremellomycetes of the phylum Basidiomycota (Kirk et al. 2008). Like other members of this phylum, these yeasts also produce laccase, a ligninolytic enzyme that allows them to grow on decaying wood and other lignified substrates (Lazéra et al. 1998, Chan \& Tay 2010).

Fungi can also be associated with many insect species. The exoskeletons of some insects can harbour several species of yeasts, promoting their survival or dispersal to new substrates (Rosa et al. 2003, Pagnocca et al. 2008). Species of Odontomachus ants, a predatory genus from the subfamily Ponerinae (family Formicidae), known as trap-jaw ants, are highly common in neotropical countries, where they interact with plants (Passos \& Oliveira 2004, Gibernau et al. 2007, Spagna et al. 2009).

To test the hypothesis that ants can act as carriers of $C$. neoformans, we examined 10 of these insects collected from a hollow of a living pink shower tree (Cassia grandis) that has been positive for this pathogen for nearly 15 years (Lazéra et al. 1996).

\section{MATERIALS AND METHODS}

Ant collection - The ants were collected in sterilised tubes from the hollow of a pink shower tree $(C$. grandis) located on the campus of the Oswaldo Cruz Foundation (Fiocruz) in the city of Rio de Janeiro (Fig. 1). The ants were transferred to the laboratory for immediate fungal isolation.

Fungal isolation from ant exoskeletons - Each ant was allowed to walk for $24 \mathrm{~h}$ on niger seed agar (NSA) plate supplemented with chloramphenicol $\left(400 \mathrm{mg} \mathrm{l}^{-1}\right)$ and amikacin $\left(800 \mathrm{mg} \mathrm{l}^{-1}\right)$. The plates were incubated at $25^{\circ} \mathrm{C}$ and examined daily for four days. During this period, phenoloxidase-positive yeast colonies were isolated and pure cultures were obtained after serial transfers on NSA. The isolates were subcultured on Sabouraud dextrose agar, stored at $4^{\circ} \mathrm{C}$ and cryopreserved in $15 \%$ glycerol at $-70^{\circ} \mathrm{C}$. 
Ant characterisation - The ants collected from the studied hollow were morphologically characterised and identified according to the literature (Kempf 1972, Brown 1976, Baccaro 2006, Bolton et al. 2006).

Yeast identification - Morphological and physiological characterisations were conducted, including phenoloxidase production on NSA, thermotolerance at $37^{\circ} \mathrm{C}$, cycloheximide sensitivity, urease production and assimilation tests performed with the VITEK-32 (bioMérieux, France). Canavanine-glycine-bromothymol blue medium was used to identify the species as $C$. gattii and $C$. neoformans (Kwon-Chung et al. 1982).

The molecular types were determined by restriction fragment length polymorphism (RFLP) of the gene URA5 according to Meyer et al. (2003). The following standard strains representing each molecular type of C. neoformans (VN) and C. gattii (VG) were included in the analysis: WM 148 (serotype A, VNI/ AFLP1), WM 626 (serotype A, VNII/AFLP1A), WM 628 (serotype AD, VNIII/AFLP2), WM 629 (serotype D, VNIV/ AFLP3), WM 179 (serotype B, VGI/AFLP4), WM 178 (serotype B, VGII/AFLP6), WM 175 (serotype B, VGIII/ AFLP5) and WM 779 (serotype C, VGIV/AFLP7).

Genomic DNA was extracted as previously described by Ferrer et al. (2001) with some modifications. Half of an inoculation loop of culture was frozen at $-20^{\circ} \mathrm{C}$ for $1 \mathrm{~h}$

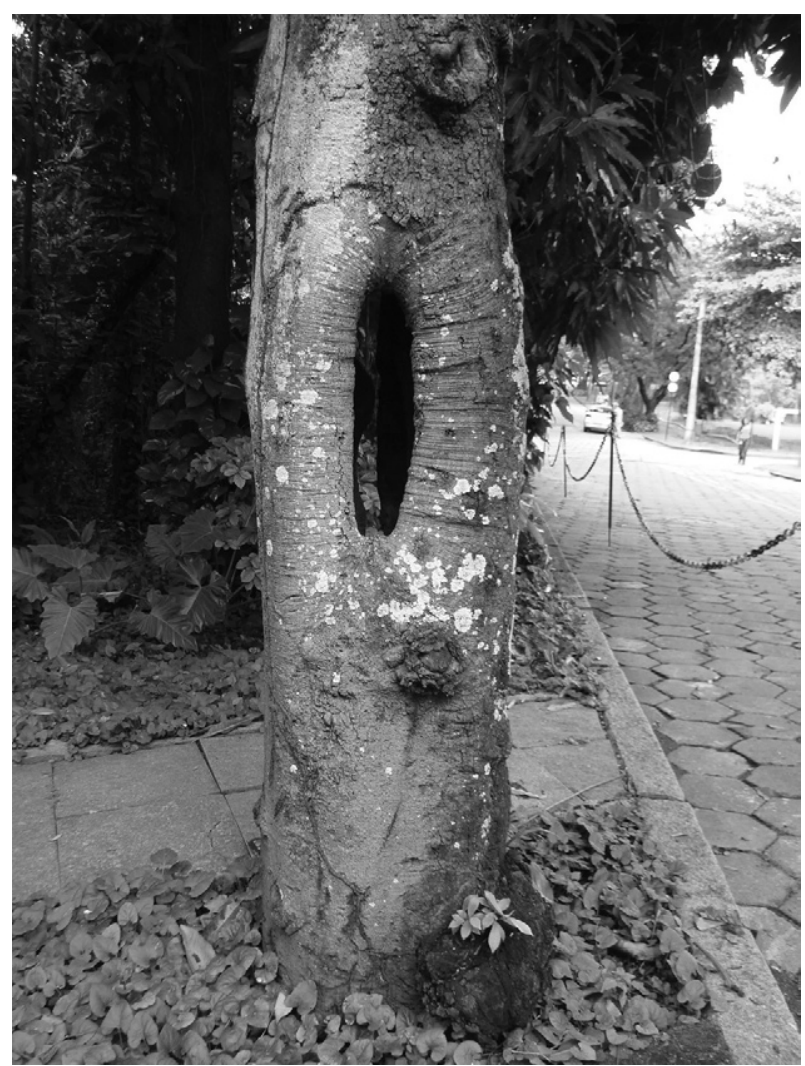

Fig. 1: pink shower tree hollow (Cassia grandis) located in the campus of Oswaldo Cruz Foundation in the city of Rio de Janeiro, Brazil, from where the ants were collected. and incubated at $65^{\circ} \mathrm{C}$ for $1 \mathrm{~h}$ in $0.5 \mathrm{~mL}$ of extraction buffer $(50 \mathrm{mM}$ Tris- $\mathrm{HCl}, 50 \mathrm{mM}$ ethylenediamine tetraacetic acid, 3\% sodium dodecyl sulphate, $1 \%$ 2-mercaptoethanol). The lysate was extracted with phenolchloroform-isoamyl alcohol (25:24:1). The DNA was recovered by isopropanol precipitation and then washed with $70 \%$ ethanol and diluted in sterile water.

The polymerase chain reaction (PCR) of the URA5 gene was performed in a final volume of $50 \mu \mathrm{L}$. Each reaction contained $50 \mathrm{ng}$ of DNA, 1 x PCR buffer [160 $\mathrm{mM}\left(\mathrm{NH}_{4}\right)^{2} \mathrm{SO}_{4}, 670 \mathrm{mM}$ Tris- $\mathrm{HCl}\left(\mathrm{pH} 8.8\right.$ at $\left.25^{\circ} \mathrm{C}\right)$, $0.1 \%$ Tween-20 (Bioline)], $0.2 \mathrm{mM}$ each of dATP, dCTP, dGTP and dTTP (Roche Diagnostics GmbH), $3 \mathrm{mM}$ magnesium chloride, $1.5 \mathrm{U}$ BioTaq DNA polymerase (Bioline) and $50 \mathrm{ng}$ each of the primers URA5 (5'ATGTCCTCCCAAGCCCTCGACTCCG 3') and SJ01 (5'TTAAGACCTCTGAACACCGTACTC 3') (Meyer et al. 2003). The target sequence was amplified in a PerkinElmer thermal cycler (model 480) using the following cycling program: $94^{\circ} \mathrm{C}$ for 2 min (initial denaturation), 35 cycles of $45 \mathrm{~s}$ at $94^{\circ} \mathrm{C}$ (denaturation), $1 \mathrm{~min}$ at $61^{\circ} \mathrm{C}$ (annealing) and $2 \mathrm{~min}$ at $72^{\circ} \mathrm{C}$ (extension) and a final extension cycle for $10 \mathrm{~min}$ at $72^{\circ} \mathrm{C}$. A total of $30 \mu \mathrm{L}$ of the PCR products was double digested with Sau96I (10 U/ $\mu \mathrm{L})$ and HhaI $(20 \mathrm{U} / \mu \mathrm{L})$ for $3 \mathrm{~h}$ and the fragments were separated by $3 \%$ agarose gel electrophoresis at $100 \mathrm{~V}$. The RFLP patterns were assigned visually by comparison with patterns obtained from the standard strains described above.

\section{RESULTS}

Two out of the 10 collected ants, later morphologically identified as Odontomachus bauri Emery, 1892, were found to carry phenoloxidase-positive yeasts. Two NSA plates allowed the growth of one dark brown colony each, later identified as $C$. neoformans molecular types VNII and VNI (Fig. 2). These isolates were deposited in the Pathogenic Fungal Collection (CFP), Clinical Research Institute Evandro Chagas, Fiocruz, as CFP 216 and CFP 217, respectively.

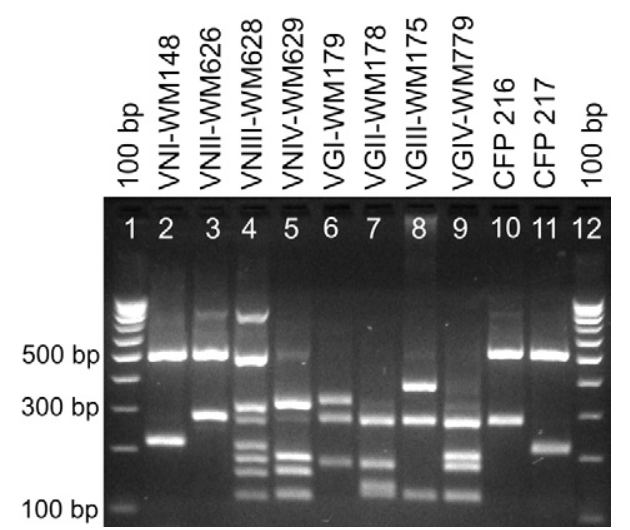

Fig. 2: banding patterns generated by URA5-restriction fragment length polymorphism. Lanes 2-9: standards strains of the major molecular types; 10-11: the two strains isolated from ants \{Pathogenic Fungal Collection (CFP) 216 [Cryptococcus neoformans (VNII)] and CFP 217 (VNI)\}. VG: Cryptococcus gattii; WM: Wicland Meyer Culture Collection. 


\section{DISCUSSION}

Fourteen hollows of living trees were formerly investigated at the Fiocruz campus. Serial scrapings taken from the inner surfaces of the hollows of two living $C$. grandis trees (family Fabaceae, subfamily Caesalpinioideae), popularly known as pink shower trees, yielded isolates of C. neoformans (Lazéra et al. 1996). The pink shower tree that provided the most isolates of $C$. neoformans (hollow A) and was continuously positive for C. neoformans until recently (M Lazéra, unpublished observations) was chosen for the current investigation. These yeasts are commonly found in this habitat, probably due to their ligninolytic enzyme laccase, which allows the yeasts to grow on decaying wood (Lazéra et al. 1998, Chan \& Tay 2010).

Fungi can be associated with different insects, such as ants, as previously demonstrated by Pagnocca et al. (2008), who isolated several species of yeasts, including Cryptococcus laurentii, from the exoskeletons of two ant species, Atta laevigata and Atta capiguara. In an earlier study, other representatives of the Cryptococcus genus were isolated from stingless bees (Rosa et al. 2003) and from the guts of insects belonging to the order Neuroptera (Nguyen et al. 2007). In another investigation, two different molecular types of $C$. gattii (VGI and VGII) were isolated from fresh insect frass (order Lepidoptera, family Oecophoridae) in a shallow cavity in the bark of a living Eucalyptus tereticornis tree (Kidd et al. 2003).

To date, there have been no reports on the association of fungi with the genus Odontomachus, although the association of these ants with bacteria has been studied (Caetano et al. 2009, dos Santos et al. 2009). The role of ants, including Odontomachus spp, as mechanical vectors of pathogenic bacteria within hospitals was recently demonstrated by dos Santos et al. (2009), uncovering a public health problem because these bacteria can be directly associated with nosocomial infections. In another study, bacteria were found in the digestive tract of $O$. bauri, the same species of ant as investigated in the present study, suggesting the participation of these bacteria in the food digestion of this ant (Caetano et al. 2009).

The finding that only two out of the 10 ants were positive for $C$. neoformans may be due to the non-homogenous presence of these pathogens in the hollow tree; these pathogens likely have a focal distribution. During sample collection, either by swabbing or scraping, it is very common to find only $10-25 \%$ that are positive. In addition, it is necessary to consider the detection limitations of the method, which can be low, in addition to the competition with other microorganisms (Mitchell et al. 2011).

The fact that the $C$. grandis tree from which the $O$. bauri ants were collected (hollow A) is very close to another $C$. grandis tree (hollow B) previously studied that is also positive for C. neoformans (Lazéra et al. 1996) suggests that the ants could be acting as mechanical vectors of $C$. neoformans and may be responsible for the dispersal of these yeasts from one tree to another. In any case, this yeast-ant association deserves more research.

In Teresina, the capital of the state of Piauí, Northeast Region, Brazil, the C. neoformans strains isolated from several trees in a single downtown square showed a high level of molecular similarity values ( $>95 \%)$ in their amplified fragment length polymorphism patterns, suggesting that cryptococcal populations may be clonally dispersed among neighbouring trees and nearby animalrelated habitats (Trilles et al. 2003).

Based on molecular typing, C. neoformans can be subdivided into the VNI, VNII, VNIII and VNIV types (Meyer et al. 1999). The C. neoformans isolates presently investigated were characterised as molecular types VNI and VNII. However, Trilles et al. (2008) molecularly typed 5 isolates of C. neoformans originating from two C. grandis trees investigated by Lazéra et al. (1996), one of which was the tree used in this study and found that all five isolates were molecular type VNI. Thus, from the first sampling (Lazéra et al. 1996) to the more recent sampling in the same hollow tree, a change in the community may have occurred, with $C$. neoformans VNII being added to the previously identified $C$. neoformans VNI. In their study, Trilles et al. (2008) analysed 320 C. neoformans isolates and $123 \mathrm{C}$. gattii isolates from various parts of Brazil, demonstrating that the most common molecular type in the southern region, which includes Rio de Janeiro, was VNI (64\%) and that VNII had a minor incidence (5\%), occurring exclusively in this region from clinical and environmental sources.

This study indicates the need for a thorough investigation with more samplings of insects, inside and around hollow trees, over an extended period of time at regular intervals to confirm that $O$. bauri and/or other insects are acting as mechanical vectors of $C$. neoformans and are responsible for the dispersal of these yeasts to other substrates. The interaction of fungi with hollow trees and insects forms a system that may be useful for understanding their ecology.

\section{REFERENCES}

Baccaro FB 2006. Chave para as principais subfamílias e gêneros de formigas (Hymenoptera: Formicidae) [monograph on the internet]. Manaus: Instituto Nacional de Pesquisas da Amazônia; 2006 [cited 2010 Oct 18]. Available from: guiasdecampo.wordpress.com/2010/12/19/chave-para-as-principais-subfamilias-egeneros-de-formigas-hymenoptera-formicidae/.

Baltazar LD, Ribeiro MA 2008. First isolation of Cryptococcus gattii from the environment in the state of Espírito Santo. Rev Soc Bras Med Trop 41: 449-453.

Bolton B, Alpert G, Ward PS, Naskrecki P 2006. Bolton's catalogue of the ants of the world: 1758-2005, Harvard University Press, Cambridge, CD-ROM.

Brown Jr WB 1976. Contributions toward a reclassification of the Formicidae. Part VI. Ponerinae, tribe Ponerini, subtribe Odontomachiti. Section A. Introduction, subtribal caracters, genus Odontomachus. Stud Entomol 19: 67-171.

Caetano FH, Bution ML, Zara FJ 2009. First report of endocytobionts in the digestive tract of ponerine ants. Micron 40: 194-197.

Chan MY, Tay ST 2010. Enzymatic characterization of clinical isolates of Cryptococcus neoformans, Cryptococcus gattii and other environmental Cryptococcus spp. Mycoses 53: 26-31.

Costa SPSE, Lazéra MSD, Santos WRA, Morales BP, Bezerra CCF, Nishikawa MM, Barbosa GG, Trilles L, do Nascimento JLM, Wanke B 2009. First isolation of Cryptococcus gattii molecular 
type VGII and Cryptococcus neoformans molecular type VNI from environmental sources in the city of Belém, Pará, Brazil. Mem Inst Oswaldo Cruz 104: 662-664.

dos Santos PF, Fonseca AR, Sanches NM 2009. Ants (Hymenoptera: Formicidae) as vectors for bacteria in two hospitals in the municipality of Divinópolis, state of Minas Gerais. Rev Soc Bras Med Trop 42: 565-569.

Ferrer C, Colom F, Frase's S, Mulet E, Abad L, Alio JL 2001. Detection and identification of fungal pathogens by PCR and by ITS2 and 5.8S ribosomal DNA typing in ocular infections. J Clin Microbiol 39: 2873-2879.

Fortes ST, Lazéra MS, Nishikawa MM, Macêdo RCL, Wanke B 2001. First isolation of Cryptococcus neoformans var. gattii from a native jungle tree in the Brazilian Amazon rainforest. Mycoses 44: 137-140.

Gibernau M, Orivel J, Delabie JHC, Barabe D, Dejean A 2007. An asymmetrical relationship between an arboreal ponerine ant and a trash-basket epiphyte (Araceae). Bio J Linn Soc 91: 341-346.

Granados DP, Castañeda E 2006. Influence of climatic conditions on the isolation of members of the Cryptococcus neoformans species complex from trees in Colombia from 1992-2004. FEMS Yeast Res 6: 636-644.

Kempf WW 1972. Catálogo abreviado das formigas da Região Neotropical (Hymenoptera: Formicidae). Stud Entomol 15: 3-344.

Kidd SE, Sorrell TC, Meyer W 2003. Isolation of two molecular types of Cryptococcus neoformans var. gattii from insect frass. Med Mycol 41: 171-176.

Kirk PM, Cannon PF, Minter DW, Stalpers JA 2008. Dictionary of the fungi, 10th ed., CAB International, Wallingford, $771 \mathrm{pp}$.

Kumar CPG, Prabu D, Mitani H, Mikami Y, Menon T 2009. Environmental isolation of Cryptococcus neoformans and Cryptococcus gattii from living trees in Guindy National Park, Chennai, South India. Mycoses 53: 262-264.

Kwon-Chung KJ, Polacheck I, Bennett JE 1982. Improved diagnostic medium for separation of Cryptococcus neoformans var. neoformans (serotypes A and D) and Cryptococcus neoformans var. gattii (serotypes B and C). J Clin Microbiol 15: 535-537.

Kwon-Chung KJ, Varma SA 2006. Do major species concepts support one, two or more species within Cryptococcus neoformans? FEMS Yeast Res 6: 574-587.

Lazéra MS, Cavalcanti MAS, Londero AT, Trilles L, Nishikawa MM, Wanke B 2000. Possible primary ecological niche of Cryptococcus neoformans. Med Mycol 38: 379-383.

Lazéra MS, Cavalcanti MAS, Trilles L, Nishikawa MM, Wanke B 1998. Cryptococcus neoformans var. gattii in a pottery tree hollow - evidence for a natural habitat related to decaying wood. J Med Vet Mycol 36: 119-122.

Lazéra MS, Pires FDA, Camillo-Coura L, Nishikawa MM, Bezera CCF, Trilles L, Wanke B 1996. Natural habitat of Cryptococcus neoformans var. neoformans in decaying wood forming hollows in living trees. J Med Vet Mycol 34: 127-131.
Lazéra MS, Wanke B, Nishikawa MM 1993. Isolation of both varieties of Cryptococcus neoformans from saprophytic sources in the city of Rio de Janeiro, Brazil. J Med Vet Mycol 31: 449-454.

Lin X, Heitman J 2006. The biology of the Cryptococcus neoformans species complex. Annu Rev Microbiol 60: 69-105.

Meyer W, Castañeda A, Jackson S, Huynh M, Castañeda E, Ibero American Cryptococcal Study Group 2003. Molecular typing of Ibero American Cryptococcus neoformans isolates. Emerg Infect Dis 9: 189-195.

Meyer W, Marszewska K, Amirmostofian M, Igreja RP, Hardtke C, Methling K, Viviani MA, Chindamporn A, Sukroongreung S, John MA, Ellis DH, Sorrell TC 1999. Molecular typing of global isolates of Cryptococcus neoformans var. neoformans by polymerase chain reaction fingerprinting and randomly amplified polymorphic DNA - a pilot study to standardize techniques on which to base a detailed epidemiological survey. Electrophoresis 20: 1790-1799.

Mitchell TG, Castañeda E, Nielsen K, Wanke B, Lazéra M 2011. Environmental niches for Cryptococcus neoformans and Cryptococcus gattii. In J Heitman, TR Kozel, KJ Kwon-Chung, JR Perfect, A Casadevall, Cryptococcus: from human pathogen to model yeast, ASM Press, Wahington DC, p. 237-259.

Nguyen NH, Suh SO, Blackwell M 2007. Five novel Candida species in insect-associated yeast clades isolated from Neuroptera and other insects. Mycologia 99: 842-858.

Pagnocca FC, Rodrigues A, Nagamoto NS, Bacci M Jr 2008. Yeasts and filamentous fungi carried by the gynes of leaf-cutting ants. $A n$ tonie van Leeuwenhoek Int J Gen \& Molec Microbiol 94: 517-526.

Passos L, Oliveira PS 2004. Interaction between ants and fruits of Guapira opposita (Nyctaginaceae) in a Brazilian sandy plain rainforest: ant effects on seeds and seedlings. Oecologia 139: 376-382.

Pfeiffer TJ, Ellis DH 1992. Environmental isolation of Cryptococcusneoformans var. gattii from Eucalyptus-tereticornis. J Med Vet Mycol 30: 407-408.

Refojo N, Perrotta DE, Brudny M, Abrantes R, Hevia AI, Davel G 2009. Isolation of Cryptococcus neoformans and Cryptococcus gattii from trunk hollows of living trees in Buenos Aires city, Argentina. Med Mycol 47: 177-184.

Rosa CA, Lachance MA, Silva JOC, Teixeira ACP, Marini MM, Antonini Y, Martins RP 2003. Yeast communities associated with stingless bees. FEMS Yeast Res 4: 271-275.

Spagna JC, Schelkopf A, Carrillo T, Suarez AV 2009. Evidence of behavioural co-option from context-dependent variation in mandible use in trap-jaw ants (Odontomachus spp). Naturwissenschaften 96: 243-250.

Trilles L, Lazéra MS, Wanke B, Oliveira RV, Barbosa GG, Nishikawa MM, Morales BP, Meyer W 2008. Regional pattern of the molecular types of Cryptococcus neoformans and Cryptococcus gattii in Brazil. Mem Inst Oswaldo Cruz 103: 455-462.

Trilles L, Lazéra MS, Wanke B, Theelen B, Boekhout T 2003. Genetic charactyerization of environmental isolates of the Cryptococcus neoformans species complex in Brazil. Med Micol 41: 383-390. 